Culture \& History Digital Journal 1(1)

June 2012, e004

eISSN 2253-797X

doi: http://dx.doi.org/10.3989/chdj.2012.004

\title{
History, Archives and the Internet
}

\author{
Jean-Claude Robert \\ Département d'histoire, Université du Québec à Montréal, Canada \\ e-mail: robert.jean-claude@uqam.ca
}

Received: 31 January 2012; Accepted: 15 February 2012; Published online: 28 March 2012

\begin{abstract}
The relationship between historians and archives is generally taken for granted. But this impression is misleading. Across the world, the building of archival collections involves a complicated process of selection and destruction. Traditionally, historians do not really know how this process is being conducted and very often a good proportion of them believe that all documents should be kept. The evolution of history and the questioning of the archives by philosophers cannot be ignored and these have changed the relationship between historians and archives. However, the construction of tomorrow's archives is happening right now, and historians should be prepared to find a way to participate in this operation. The role of archivists is central in the whole process. In the past, archivists generally received a basic training as historians, but since the 1950s, they have been more and more involved with other disciplines like library or information sciences. They became professionals in a new discipline. Historians should take notice of this reality and be prepared to work with archivists on an equal footing. They must learn what archivists are doing and join them to help create archival collections for the future. The last part of the paper takes a quick looks at the evolution of the Internet as an addition, or rather than as an extension, of archival holdings.
\end{abstract}

KEYWORDS: construction of tomorrow's archives; archive; record; history; archivist; historian.

Citation/Cómo citar este artículo: Robert, J.C. (2012) "History, Archives and the Internet”. Culture \& History Digital Journal 1(1): e004. doi: http://dx.doi.org/10.3989/chdj.2012.004

RESUMEN: Historia, Archivos e Internet.- La relación de los historiadores con los archivos se considera segura, pero esta impresión confunde. En todo el mundo, la construcción de colecciones de archivo supone un complejo proceso de selección y destrucción. Los historiadores no suelen conocer este proceso, creyendo que todos los documentos se conservan. La evolución de la historiografía y el cuestionamiento de los archivos por los filósofos no se pueden ignorar, pues han cambiado la relación entre historiadores y archivos. Pero la construcción de archivos futuros sucede hoy, y los historiadores deben estar preparados para esa operación. El papel de los archiveros es central, antes solían recibir formación básica en historia, pero desde los años 1950 están cada vez más implicados con otras disciplinas, así biblioteconomía y ciencias de la información, formándose como profesionales en una nueva disciplina. Los historiadores deben conocer esta realidad y prepararse a trabajar con los archiveros en pie de igualdad, sabiendo lo que estos hacen, uniéndose a ellos para crear las futuras colecciones de archivo. En fin, se proporciona una mirada a la evolución de Internet como una adición, o mejor como una extensión de las riquezas de los archivos.

PALABRAS CLAVE: construcción de futuros archivos; archivo; registro; historia; archivero; historiador

Copyright: (C) 2012 CSIC. This is an open-access article distributed under the terms of the Creative Commons Attribution-Non Commercial (by-nc) Spain 3.0 License. 
The relationship between historians and archives is taken for granted most of the time, but there is a certain misunderstanding between historians and archivists and it might become the source of many problems in the future, especially for the construction of tomorrow's archives. Today, a huge amount of documents are being produced and processed by public administrations and governments at all levels. After a few years, this mass is reduced by an operation which transfers a small proportion to an archival collection, and the rest is destroyed. Most historians do not have experience with the process leading to the construction of archives. Generally, archives from the earlier periods, before 1900, are well known and securely preserved. Moreover, the mass of documents is still relatively manageable.

During the last century, there was another important development for historians in relation to archival material. Primary sources became much more diversified and any trace of human action became useful material. However, the more traditional official documents of state are still being produced and they are still indispensable to the historian. In addition, during the last century, the state, through its increasingly diverse administrations, has played a greater role in the life of citizens. What about this mass of information? Why not keep everything? How will it be preserved for the future?

I lost my innocence twenty years ago when I was asked to sit on an Interdepartmental Committee set up to investigate the accumulation of court records in the Province of Quebec. Since the 18th century, not a single scrap of paper had been destroyed in the documents produced by the day-to-day operations of law courts and already some 120 linear kilometers of shelf space were occupied. But more troubling was the fact that, in the 1980s, this body was growing at an ever-faster rate: every year, 6 kilometers of documents were being added. The problem was pressing. For example, in 1971, a new much larger courthouse was opened in Montreal and it was believed that there was enough room to hold all records for the next 25 years. A mere 10 years after, storage capacity was already overflowing and the Department of Justice had to rent additional space in scattered locations. In addition, this mass of archives was inaccessible because of the absence of any archival processing. More troubling was the fact that, for the first time in my professional life, I was asked to decide which documents would end up in the archives and which documents would be destroyed. The final report of the Committee proposed a drastic reduction in the documents to be kept, especially those produced after the 1960s (Gouvernement du Québec, 1989). I felt almost that I was party to a crime! (Robert, 1991).

\section{HISTORIANS AND ARCHIVES: AN AMBIGUOUS RELATION}

Historians often have a curious behavior with archives. They are keen to look for archival documents or series, sometimes to criticize them, but all too often they ignore completely the political and economic context of their creation and preservation. This is especially true of the archives that are actually in the process of moving from the creators to some form of storage. When confronted with the question of appraisal, which means the necessary selection and eventual destruction of documents, they almost invariably ask the question: "Why not keep everything?" This line of reasoning is exactly as if one would consider that every scrap of paper is an irreplaceable piece of the past.

But, at another level, in the second half of the 20th century, the preoccupations of historians shifted from the criticism of the archival document to a criticism of current historical methods and approaches. Historian Geoff Eley summarized the main changes in his book: A Crooked Line. From cultural history to the history of society (Eley, 2005). After the heyday of social history in the sixties and seventies, came a time of doubt in the 80 s and 90 s, during what is called the "linguistic turn" and then the "cultural turn". Historians became more aware of the limits of sources and approaches and in particular the weight of objectivism. This changed the relation to archives. It is also telling that the questioning of archives came from outside the mainstream of history. It was Michel Foucault (1969) who offered a new definition of the archive. He was not alone, since philosopher Jacques Derrida later proposed his own reflections on the archive in Archive Fever: A Freudian Impression (Derrida, 1998; Tyacke, 2001; Steedman, 2001). What Foucault and Derrida had in mind, however, was something different than archives as a collection of documents or as a repository, but in the wake of the debates that followed, historians became aware of the multiplicity of meanings of documents, and developed a different perspective on archives, involving a sweeping reconsideration of the way sources could be utilized. As Eley wrote, “...existing archives aren't exactly the neutral storehouse of the entirety of the past record implied by a traditional «objectivist» stance". And he goes on to say: "... archives are extraordinary partial and contingent things" (Eley, 2005:164). In the end, historians were encouraged to go further than simple classical historical criticism, to question the way the archives were constituted, and to a certain extent, to try to become aware of what was left out and why.

However, if this operation was long overlooked by historians, archivists had been performing the 
task and had produced a number of introductions documenting the constitution of the various series of their holdings. But, historians tended to avoid finding out about that operation. Quite often they found the long introductions in the various Finding Aids rather tedious and for some, these were perceived as a kind of veil between the archival document and the historian (Grimard, 2009:113).

But, while these reflections continued to be front and center, the question of the creation of tomorrow's archives remained almost untouched by historians, in particular the complicated process involving appraisal, selection, elimination and conservation. This was happening in a very specific context: that of a real explosion in the production of documents. Since the 1970s, not only the regulatory activities of governments increased tremendously, but on a technical level, the wider use of photocopy, word processors and later the personal computer drastically changed the situation. Everywhere, reams of documents, often in multiples copies, started to accumulate and to clog files. At the same time, most societies in the West were becoming more and more concerned with their history.

What should be done? Very clearly the cost of record keeping started to increase: not only were there more and more documents to be preserved, but the physical conditions of conservation became more sophisticated, and of course costlier. In addition, more people wanted access to these records and to better facilities for the consultation of documents.

But who does it? During the 20th century, archivists became central in this process while at the same time, becoming more and more estranged from historians. If training in history had been the main requisite to work in many archival services before 1950, it quickly lost its monopoly position afterwards (Robert, 1990).

\section{HISTORIANS AND ARCHIVISTS: AN UNEASY RELATIONSHIP}

Historians tend to ignore the fact that the profession of archivist did undergo a profound transformation especially after the 1970s. Nowadays, many archivists, if not most of them, do not identify their work as being solely and exclusively linked to history. However, the romantic image of French historian Jules Michelet (1798-1874), roaming the corridors of the National Archives in Paris and later sitting down at his desk to write the History of France still looms large in the memory of many historians (Hartog, 2007:190201; Arlettaz, 2003-2004:7). Even if this image might seem a bit of a caricature, in general historians remain unaware of the change and still consider archival work as a kind of auxiliary science, in the somewhat condescending terms of the classic manuals of historical methods. The archivist is seen simply as a keeper and provider of documents, in short, as a kind of handmaiden to history. Of course, in his spare time, he might use the archives to write history himself as was so often the case before 1960, but this is no longer a professional objective. Archivists no longer accept such a condescending attitude from historians and they resent it. They have developed their own profession and from simple custodian of archives, have become full-fledged professionals in their diverse capacities and duties.

This is not the place to recount the evolution the archival sciences, but some clarification should be provided. First there is the traditional distinction between the so-called three ages of archives. The life cycle of documents has three steps: first records are active, in the sense that they are produced and used in the framework of a definite administrative process, mainly by their creator. Then follows a second phase, called semi-active, during which records are still used, but not regularly, and finally a last phase, when records are inactive, that is, not required any longer for the administrative process for which they were created. Nowadays, this theory of the three ages is criticized but it is still in use, even though the notion of a continuum has been proposed to replace it.

But, in the meantime, the application of the notion of the three ages brought about a distinction between archives and records. The first term designates those records that are to be kept for a long time, and most historians are quite familiar with these. The second term designates any documents produced by an administration in its day-today business. It is a generic term and covers all possible documents, in whatever form they might take. This distinction brought a lot of internal discussions among archivists, and almost created a rift between two schools or two approaches: those who saw themselves mostly as Records managers and those who insisted on the ultimate goal of producing archives. Internationally, situations are quite diverse. For instance, in the USA and Britain, records management quickly became very important, as exemplified by the influence of Theodore Schellenberg (1903-1970) and Sir Hilary Jenkinson (1892-1961) (Lodolini, 1989). Their work also lead to an attitude of defiance vis-à-vis the historical profession. Jenkinson, for one, did not see any role for historians in the appraisal process, which he felt should be entirely left with the primary producer, the creator of the documents. But now the rift seems much less important as archivists have developed various methods to appraise documents. Nowadays, the profession is increasingly drawn to library science, information sciences and managerial sciences. However, many archivists retain a 
strong attachment to the importance of history (Nesmith, 2004; Tyacke, 2001; Arlettaz, 2003-2004) and also to the intellectual context of social science more generally (Cook, 2001). But clearly, historians have to reach out to archivists and maintain contact.

Over the years, archivists have developed a unique expertise with documents. Through the "Records retention and destruction schedules" (in French calendriers de conservation) that imposes an inventory of documents produced, they were able to have a better perspective on the growth of government documents. In many ways, procedures went from implicit to explicit, thus helping the decision-making process and documenting the selection of documents. As a matter of fact, archivists are performing a good proportion of the work of criticism of sources and this is a direct benefit to historians who can build further from this. Moreover, as many countries decided to enact archival laws in the second half on the 20th century, these laws imposed a minimum form of stock taking of the documents produced by a public administration in its day-to-day business. Thus it became possible to know what kind of documents were produced and what was their expected life span. The multiplication of freedom of information laws made some documents accessible to citizens, and helped to change the picture and gave a new role to archivists.

The construction of tomorrow's archives is not and should not, however, be reserved exclusively for archivists. The archival laws around the world created new social responsibilities for both archivists and historians and in that sense, it is the duty of historians to respond to the challenge. But, to achieve cooperation historians should be more proactive and instead of lamenting the transformation of archivists and their being seemingly aloof from history, they must work more closely with them.

More important still, historians have to learn a few things. The first is that not all documents can be kept indefinitely in the archives. Secondly, that the transfer of documents to a different medium is not a universal solution. Without going into details, all technologies have their flaws and almost none is specifically devised to withstand the passage of time. As for paper documents, in the past, archivists calculated that only 5 to $15 \%$ of the documents produced by governments during the first half of the 20th century ended up in the archives. Now it seems that this figure is even lower at fewer than $5 \%$. Thus there is the inescapable necessity of selection and destruction in order to ensure that something significant is kept. As an executive at the British Library remarked: "Disposal is undoubtedly a difficult and emotive issue" (Schwirtlich,
2002:60). However the selection process is indispensable to ensure a minimal organization of archival material and to provide access. A huge mass of unorganized documents is not very useful for historical research.

Even now, as government documents are increasingly in digital form - it is estimated that from $80 \%$ to $90 \%$ of documents produced by governing bodies in North America are in digital form, their conservation is already problematic and poses a challenge to archivists all over the world. The problem is complex and has technological and archival dimensions. Technology change constantly and we are not sure to be able to recover old data and moreover there is no such thing as an "original" digital document to be kept as reference.

This points to the centrality of the documentary appraisal process. In this process, historians can play a role. Many countries have an advisory board for their archives and these should be used. For instance, in 1997, Britain decided to review selection criteria for archives that had been established during Sir Hilary Jenkinson's term of office (19471954) and that seemed inadequate. A wide consultation of various user groups was launched and historians played a prominent role (Simpson and Graham, 2002). Furthermore, this consultation will occur regularly in the future to keep abreast of the needs of users.

However, in the past, this process was made on a document-by-document basis. But the tremendous increase in volume in the recent years makes such an approach impossible now. To give but one example, in Britain, for the years 1970-1974 and for a single department, the volume of records to be appraised doubled! New methods are being devised, like Macro-Appraisal and Functional Analysis, which enable larger volumes of documents to be processed. Whatever the outcome, historians have to be sure to be included in the process. And the involvement of historians will come none too soon. As one archivist wrote, "There is even a danger in abolishing the connection with history" (Frederiksson, 2002:42).

\section{THE INCIDENCE OF INTERNET}

The Internet is quickly gaining importance as a research tool and it is in a constant state of flux. Not long ago, academics were criticizing the quality of information available but now it seems that the advantages far outweigh the shortcomings and like many colleagues I frequently start my own research by a quick check with Google. . (Conrad, 2007).

The Internet represents a relatively simple solution for archives. There is less need for research space in archival buildings and the search and 
retrieval of documents do not monopolize personnel. Easy and almost universal access is another advantage. Also, as a regular user of old maps, I find it more useful to be able to work online on digitally enlarged sections of maps instead of having to use the often unwieldy and fragile original, which implies a lot more handling operations and practical difficulties.

Archives as well as other institutions are quickly developing their on-line offer and giving increasing access to all kinds of information. However, there is also one potential problem and it is linked to institutional politics. The scramble for visibility and identity by political institutions threatens to weaken the status of the National Archives in many countries. For instance, in Canada and in France, many state institutions now have their own Internet portal and they have put series of documents online. Of course, this multiplication of archival holdings is not a problem in itself, but it may lead to a dilution of personnel in the principal archival institution. As a matter of fact, the process of archival appraisal requires a team of trained archivists and there is a risk in dispensing with their presence.

Aside from national institutions, there are now all kinds of private archives accessible on the Internet and this is probably bound to increase with time. Researchers now have access to a huge range of archival holdings. However, the problem of quality assessment remains and it will continue to be the user's responsibility.

The vexing question of permanence will remain: sites come on-line and disappear after a while, some quite rapidly. Even if some forms of Internet archives exist, their retrieval it is not always convenient and, moreover, the whereabouts of the files will be harder to document.

Finally, there is the danger for falsification. For example it is quite possible to take a digitized copy of an old map and use a mapmaking program to produce an altered version. Very clearly the necessity of comparing originals with to on-line collections once in a while will remain. But what about the present day maps, already created by a computer? How is their preservation and authenticity to be ensured?

I will conclude by stressing again that it is important for historians to maintain contact with archivists and to keep abreast of their reflections. We have to develop ways of improving collaboration with them in order to develop the archives of the future. For this, historians have to be prepared to give full recognition to archivists as professionals and to recognize the importance of their work in documenting the creation of records and their whereabouts before they get filed in an archive. This means that historians must go the distance and take an interest in the development of archival science and discover for themselves what archivists have to say. The Internet, on the other hand, will change the way historians access archives. It will be essential to follow up on future developments in that field.

\section{ACKNOWLEDGEMENTS}

This paper is based on a lecture given Presented to a Symposium of the International Committee of Historical Sciences and the Association of Japanese Historians, University of Tokyo, 11 Sept 2009. I would like to thank the Japan National Committee of Historical Sciences for their hospitality. Thanks also to professors Shigekazu Kondo of the University of Tokyo, Joanne Burgess and Marcel Caya from Université du Québec à Montréal (UQAM) for their comments.

\section{REFERENCES}

Arlettaz, Gérard (2003-2004) "Pour une démarche historienne et scientifique des Archives". Archives, 35: 5-18. http://www.archivistes.qc.ca/revuearchives/vol35_1_2/35-12-arlettaz.pdf [accessed 09/February/2012]

Conrad, Margaret (2007) "2007 Discours de la présidente de la S.H.C. L'histoire publique et le mécontentement qu'elle suscite ou L'histoire à l'ère de Wikipedia". Journal of the Canadian Historical Association/Revue de la Société historique du Canada, 18: 1-26. http://id.erudit.org/ iderudit/018253ar [accessed 09/February/2012]

Cook, Terry (2001) "Fashionable Nonsense or Professional Rebirth: Postmodernism and the Practice of Archives". Archivaria, 51: 14-35. http://journals.sfu.ca/archivar/ index.php/archivaria/article/view/12792/13989 [accessed 09/ February/2012]

Derrida, Jacques (1998) Archive Fever: A Freudian Impression. Translated by Eric Prenowitz. University of Chicago Press.

Eley, Geoff (2005) A Crooked Line. From Cultural History to the History of Society. Ann Arbor, The University of Michigan Press.

Foucault, Michel (1969) L'Archéologie du savoir. Gallimard, Paris.

Frederiksson, Bernt (2002) "The Changing Role of Archivists in the Contemporary Society". COMMA: International Journal on Archives, 1-2: 37-43.

Gouvernement du Québec (1989) Rapport/du Comité interministériel sur les archives judiciaires. Ministère des affaires culturelles et Ministère de la justice. 3 volumes. Montréal.

Grimard, Jacques (2009) L'archivistique à l'heure du paradigme de l'information ou la "Révolution" numérique à l" "âge" archivistique. In: L'Archiviste, constructeur, gardien et communicateur. Mélanges en hommage à Jacques Grimard 1947-2007, pp 87-118, edited by Yvon Lemay and Louise Gagnon-Arguin. Presses de l'Université du Québec.

Hartog, François (2007) Evidence de l'histoire. 2nd Edition. Gallimard, Paris

Lodolini, Elio (1989) "The War of Independence of Archivists". Archivaria 28: 36-47. http://journals.sfu.ca/archivar/index. $\mathrm{php} /$ archivaria/article/view/11569/12515 [accessed 09/ February/2012]

Nesmith, Tom (2004) "What's History Got to Do With It? Reconsidering the Place of Historical Knowledge in Archival Work". Archivaria 57: 1-27. http://journals.sfu.ca/ archivar/index.php/archivaria/article/view/12450/13552 [accessed 09/February/21012]

Robert, Jean-Claude (1990) "Dicours du président: Historiens, archives et archivistes: un ménage à trois". Journal of 
the Canadian Historical Association/Revue de la Société historique du Canada, 1: 3-15. http://id.erudit.org/iderudit/ 031008ar [accessed 15/February/2012]

Robert, Jean-Claude (1991) L'histoire et ses méthodes: À propos des archives judiciaires. Archives, 22(4): 91-103.

Schwirtlich, Anne-Marie (2002) The Functional Approach to Appraisal - the experience of the national Archives of Australia. COMMA: International Journal on Archives, 1-2: $57-62$.
Simpson, Duncan and Susan Graham. (2002) Appraisal and selection of Records: A New Approach. COMMA: International Journal on Archives, 1-2: 51-56.

Steedman, Carolyn (2001) Dust. Manchester University Press. Tyacke, Sarah (2001) "Archives in the Wider World: The Culture and Politics of Archives." Archivaria 52: 1-25. http://journals.sfu.ca/archivar/index.php/archivaria/article/ view/12812/14017 [accessed 07/February/2012] 